UDC 341.382(497.6)"1995"

DOI: https://doi.org/10.18485/iipe_ria.2020.71.1179.1

Biblid 0543-3657, 71 (2020)

Vol. LXXI, No. 1179 , pp. 5-20

review paper

\title{
DAYTON LEGACY - 25 YEARS OF BUILDING PEACE IN BOSNIA AND HERZEGOVINA
}

\author{
Sandra DAVIDOVIĆ ${ }^{1}$
}

\begin{abstract}
A quarter of a century since peace was achieved in Bosnia and Herzegovina through the signing of the Dayton Peace Agreement represents an occasion to consider the scope of the agreement and make an assessment of the Dayton peace legacy 25 years after. This paper discusses the circumstances that postponed the final peace agreement in Bosnia and prolonged the war for three years, as well as the political environment that finally instigated successful negotiations finalized in reaching the Dayton Agreement. From the moment the agreement entered into force until today, it has been an object of various criticisms, which have often neglected the complex circumstances in which it was reached, as well as the importance of its crucial achievement - peace. The Dayton Agreement, which put an end to the civil war, can only be assessed to a limited extent, having in mind that a significant time distance is still required. In this paper, the scope of the agreement's legacy will be considered in relation to two basic functions: peacebuilding and state-building in Bosnia, whereas we assume that these two functions are highly conditioned, and therefore any assessment should be understood in the wider context including both dimensions.
\end{abstract}

Keywords: Bosnia, civil war, Dayton agreement, peacebuilding, state-building.

\section{INTRODUCTION}

One of the changes that marked the post-Cold War conceptual turmoil concerned the notion of the state. (Woodward, 2009a, p. 316.) Unlike the Cold War perception, according to which a strong state (sovereign state) was considered

\footnotetext{
${ }^{1}$ Research Assistant, Institute of International Politics and Economics, Makedonska 25, Belgrade, email: sandra.davidovic@diplomacy.bg.ac.rs

The paper presents findings of a study developed as a part of the research project "Serbia and challenges in international relations in 2020", financed by the Ministry of Education, Science, and Technological Development of the Republic of Serbia, and conducted by the Institute of International Politics and Economics, Belgrade.
} 
as a primary threat, the new interest of international actors in intervening is related to the reinterpreted concept of security, according to which weak and dysfunctional states (fragile states) are seen as a source of challenges and risk on both regional and global level. In this regard, the understanding of sovereignty has changed as well, which has started to be identified with the administrative capacity, rather than with the political content. Consequently, state-building appears to be a perfect reverse solution in this regard. Namely, if state sovereignty is defined in terms of institutional capacity, instead of the usual understanding of political independence, then the state-building interventionism appears as a means of strengthening sovereignty, not its undermining, which overcomes one of the basic criticisms on interventionism. Although the explicit interventions during the 1990s represent only two aspects of the vast state-failure debate - the humanitarian and spillover consequences of violent conflict over the state and the post-war state-building operations -the current international consensus that civil wars are a threat to global security, and that both international peace and local development depend on the complex state-building interventions to build effective and legitimate states, began with the intervention in Bosnia and Herzegovina after the negotiated peace agreement of November 1995. (Woodward, 2009a, p.320) Albeit it has passed 25 years since the war in Bosnia ended, this case still draws the attention of many, asking whether the large scope intervention of state-building in Bosnia, based on the framework of the Dayton Agreement, provided the foundation for sustainable peace and viable state apparatus. This is of particular importance since the Yugoslav cases of peacebuilding and state-building interventions are perceived as a starting point in setting the initial state-failure agenda. (Woodward, 2009a, p.319) Additionally, the breakup of the Federal Republic of Yugoslavia has evolved into a highly illustrative example of a divide among the states in numerous issues of international law, most notably in their positions concerning people's right to selfdetermination and the territorial integrity of the state. Furthermore, the former Yugoslavia has come to be one of the most complex 'collections of challenges' facing international institutions and organizations with the post-Cold War order. It has tested the Western concept of security in an unprecedented way after the Second World War. Additionally, current security and political conditions in the region of the Balkans warn that any final closure of examination of the Yugoslav war would prevent us from new findings on its root causes and understanding of alternative political and institutional solutions. In an attempt to provide a modest contribution in assessing the reach of the Dayton Agreement, this paper seeks to examine its legacy, by analyzing the two major dimensions, establishing sustainable peace and creating an effective state as part of the larger framework of the state-building interventionism. The first dimension is related to the goal of ending atrocities and related peacebuilding efforts, while the second one touches upon 
the effectiveness of state organization and the quality of governance created by the agreement. Although they are inextricably linked, it can be hardly denied that achieving peace was crucial in the building of any type of state in Bosnia, like any institutional capacity is unquestionably conditioned by the building of a sustainable peaceful environment. Therefore, we must consider the dual essence of this agreement and make an assessment within such a context. Vast criticism of the agreement largely ignores this essential duality, which results in outweighing its positive function (embodied in providing peace in Bosnia). Critiques of the functionality of the state represent an analysis of the program implementation only, with reducing the complexity of peacebuilding in Bosnia to the aspect of efficiency. Having in mind the political and historical environment in which the state-building program was carried out in Bosnia, the use of the state as a unit of analysis and focusing on endogenous political processes gives only superficial insights. In order to overcome those constraints, we will seek to consider the scope of peacebuilding in the context of the broader historical and political circumstances in which the agreement was reached.

\section{CLASH OF NARRATIVES: FROM AGGRESSION TO ETHNIC WAR}

After two of the country's six constituent republics - Slovenia and Croatia, declared independence, the Yugoslav state failed. However, the label adopted by internationals was not "state failure". (Woodward, 2009a, p. 321) Namely, in order to resolve complex legal issues arisen from the breakup of the country, the European Community's ad hoc commission of jurists - the Arbitration Commission of the Peace Conference on Yugoslavia (Badinter Arbitration Committee $)^{2}$ concluded in its first advisory opinion that "the Socialist Federal Republic of Yugoslavia is in the process of dissolution". (Badinter Commission Opinion No. 1, 1991) Answering the question of whether the secession of some republics from the SFRY preserved its existence or caused its dissolution with all the republics being equal successors to the SFRY ${ }^{3}$, the commission avoided

\footnotetext{
${ }^{2}$ The Committee was chaired by Robert Badinter, President of the French Constitutional Council, and was furthermore comprised of the Presidents of the German and Italian Constitutional Courts, the Belgian Court of Arbitration, and the Spanish Constitutional Tribunal.

${ }^{3}$ The President of the Arbitration Committee received the following letter from Lord Carrington, President of the Conference on Yugoslavia, on 20 November 1991: Serbia considers that those Republics which have declared or would declare themselves independent or sovereign have seceded or would secede from the SFRY which would otherwise continue to exist. Other republics on the contrary consider that there is no question of secession, but the question is one of disintegration or breaking-up of the SFRY as the result of the concurring will of a number of republics. They consider that the six republics are to be considered equal successors to the SFRY, without any of them or group of them being able to claim to be the continuation thereof.
} 
resolving the equation which consisted of the clash between two principles: territorial integrity and self-determination. Contrary, by choosing to qualify this case using the somewhat invented political term, with no legal clarity, it created a space for further inconsistency in interpretation. Soon after "this camouflage for secession succeeded and fighting began over where the borders of the new states in this territory would be, the EU shifted to the principle of territorial integrity, applied now to the borders of the federal republics in the former state". Therefore, "any challenge to these borders made with force would be an act of state aggression in violation of the UN Charter". (Woodward, 2009a, p.321) This understanding has drastically affected the approach in resolving conflict in Bosnia in which each of three ethnic groups - Muslims, Serbs and Croats, were asking for their right of self-determination. This is, on the other hand, highly related to the broader issue of defining the nature of the Yugoslav war, which has deeply divided involved international actors and affected the scope, intensity and duration of the war, particularly in multinational Bosnia. Namely, as Susan Woodward states, there were two major interpretations of the nature of the Yugoslav war, and consequently of the Bosnian war, which is of particular interest for this paper. According to the first perception, mainly favored in the United States, but originally coming from Austria, Germany, Slovenia and Croatia, the war in Bosnia represented aggression of Serbia towards a sovereign state and a member of the United Nations. ${ }^{4}$ The second interpretation qualified this conflict as a post-communist civil war, whereas it was mainly accepted in Europe and Canada, with minor acceptance in the US as well. (Woodward, 1995b, pp. 18-19) According to the nature of these interpretations, the proposed approach in resolving the conflict was contradictory and unclear from the beginning of international involvement, which reflected a wider crisis in leadership and relationship within Western countries. Based on the belief that the cause of the war in Bosnia was Serbian aggression, the proposed solution within the first group of opinion included punishment of the aggressors: political isolation, economic sanctions, and military threats. On the other hand, acknowledging three parties' conflict, the second interpretation emphasized the importance of political consent of each of the conflicting sides, as part of a peaceful resolution. This was particularly important for the countries present on the ground (as part of UN peacekeeping mission), which claimed that an early ceasefire is an important precondition for the work of negotiators. (Woodward, 1995b, p. 19) On the contrary, the first approach has treated the early ceasefire as the recognition of the Serbian territorial advantage, which will consequently result in awarding the aggression. The years before the agreement were marked by a clash of those

\footnotetext{
${ }^{4}$ Soon after declaring independence and recognition by the European Communities and the United States, Bosnia became a Member State of the United Nations on May 22, 1992.
} 
narratives and bloody consequences caused by the absence of a unique approach and strategy to end a war. The disagreement in defining the causes of the war, and America's tendency to favor a solution based on the first interpretation of the conflict, together with an unwillingness to engage militarily in the war, prolonged the uncertainty and postponed the final agreement, which cost more than 100,000 victims and over two million refugees. This seems to confirm an uncertainty of the concept of the state-building interventionism, showing how politicized its implementation appears to be. Although introduced as a response to security challenges based on local ownership, ultimately, the content and the form (the timing as well in the case of Bosnia) of the program of state-building were deeply linked to the interests of the intervening states. However, as it will be presented later, a major criticism on the lack of creating effective governance in Bosnia and implementing foreign-based arrangements will come from organizations and countries that determined a state-building agenda based on their political and security needs in the region, which frequently did not correspond to the Bosnian reality and therefore tied hands of local actors in becoming accountable for the post-war transition.

\section{THE PRE-DAYTON PERIOD - YEARS OF WAR}

Encouraged by the recognition of Croatian and Slovenian independence, the Muslim and Croatian parties in the Bosnian parliament ${ }^{5}$ passed a Memorandum of Sovereignty on October 15, 1991. The Serbian party declared the Memorandum unconstitutional, primarily because it was not voted by a twothirds majority, which was required by the Republic constitution. The European Community initially rejected the request for the recognition of Bosnia, demanding a referendum in which all citizens of that republic would participate. ${ }^{6}$ However, one cannot deny that the EC should have known that the Serbian Democratic Party would oppose the referendum since the major aim of the party was to prevent Serbs to become a minority in the Republic of Bosnia and Herzegovina. (Woodward, 1995b, p. 274) Namely, when Yugoslavia came to the point of dissolution in 1991, for Serbs it was the ending of a state in which they all lived together. For others, it was a continued movement towards selfdetermination. In the context of Bosnia, Serbs preferred to remain part of the

\footnotetext{
${ }^{5}$ The Parliament was constituted after first democratic elections in 1990 and ruled by three ethnicbased parties that gained the majority of votes: the Party of Democratic Action representing Muslims, the Croatian Democratic Union representing Croats and the Serbian Democratic Party representing Bosnian Serbs.

${ }^{6}$ It was an opinion of the Badinter Commission that the referendum should include the majority of voters from each of three major ethnic groups, in order to be perceived as legitimate.
} 
Yugoslav federation to becoming a permanent minority in a newly independent state. Hence, the referendum vote divided Bosnia along ethnic lines. While Muslims (represented 44 percent of the republic's population) and Croats (17 percent of the republic's population) strongly favored independence, Serbs (31 percent of the republic's population) opposed any secession of Bosnia and boycotted it, declaring it unconstitutional. After $99 \%$ of the valid votes favored independence, the Muslim-Croat coalition declared independence on March 3, 1992. (Paris, 2004, p. 97) Although the Badinter's opinion on the referendum was obviously ignored, the European Community and the United States recognized the country's independence a few days after. The premature recognition created great resistance among Serbs whose demands for self-determination, as previously in Croatia, were largely ignored. It was not clear that without resolving their right to self-determination, Serbs would not accept a sovereign Bosnia. This became clear soon after the recognition. (Woodward, 1995b, p. 278) Following the resignations of the Serbian representatives in the collective Bosnian presidency, the Serbian Republic of Bosnia and Herzegovina declared its independence on 7 April 1992. ' According to the party, the independence of Bosnia would result in Serbs becoming "a national minority in an Islamic state". (Toal, Dahlman, 2011, p. 110) However, once Bosnia's independence was recognized $^{8}$, there was a lack of internationally led military engagement aimed at protecting the newly created state. Namely, the belief that the Yugoslav war does not represent a significant threat to the national security of major Western countries, together with the disunity of allies regarding both causes and approach in resolving the Yugoslav crisis, prevented large scale international involvement.

\footnotetext{
${ }^{7}$ Previously the Serbian Democratic Party formed the Assembly of the Serb People of Bosnia and Herzegovina and held a referendum about remaining within Yugoslavia. In January 1992, the assembly declared the creation of the Republic of the Serb People of Bosnia and Herzegovina, a Serb controlled part of Bosnia.

${ }^{8}$ Encouraged by the recognition of Croatian and Slovenian independence, the Muslim and Croat parties in the Bosnian parliament passed a Memorandum of Sovereignty by a simple majority on October 15, 1991. The Serbian party declared the memorandum unconstitutional, primarily because it was not passed by a two-thirds majority which was required by the republican constitution. The European Community Arbitration Commission initially rejected the request for the recognition of Bosnia, demanding a referendum in which all citizens of that republic will participate. The vote divided Bosnia along ethnic lines. While Muslims (represented 44 percent of the republic's population) and Croats (17 percent of republic's population) strongly favored independence, Serbs (31 percent of republic's population) opposed any secession of Bosnia and opposed it, declaring it unconstitutional. After $99 \%$ of valid votes favored independence, the Muslim-Croat coalition declared independence on March 3, 1992. The European Community and the United States recognized the country's independence a few days after. This was a prelude to a bloody Bosnian war, which will prove to be one of the major threats to the post-Cold War security institutions.
} 
Finally, the reluctance of engagement of the remaining superpower in the early stages of war contributed to an unclear approach in resolving the war. ${ }^{9}$ However, it became clear soon that what was seen as a conflict of minor importance was transformed into a bloody civil war and major security threat in Europe after the Second World War. From declaring Bosnia's independence in March 1992, up to the Dayton Agreement reached in November 1995, "sporadic fighting between paramilitary groups of the three major ethnic groups ${ }^{10}$ developed into a full-scale civil war, despite several short-lived cease-fires". (Paris, 2004, p. 98) On the battlefield, Serbs had more success and managed to conquer $70 \%$ of the country's territory by the end of 1993. In parallel with war atrocities, there were several internationally led attempts to mediate a negotiation of the settlement of the conflict. These attempts, mainly consisted of the European Communities' diplomatic initiatives, repeatedly proved the incapability of the EC newly established foreign policy to deal with serious security threats. Affected by capability - expectation trap that marked its engagement throughout the entire Yugoslav war, together with the fact that they were politically and militarily marginalized by the US, they failed to achieve a necessary ceasefire. The initial response of the international community towards the war was a deployment of the United Nations peacekeeping mission ${ }^{11}$, aimed at ensuring the delivery of humanitarian aid, which was far from enough to reduce the violence. Later extensions of the mandate of the UNPROFOR to protect civilian 'safe areas' will prove to be a great failure, mainly because the peacekeeping mandate of the mission, together with present humanitarian organizations were neither prepared nor equipped for the war. By the summer, the situation had become alarmingly dangerous, resulting in the withdrawal of the International Committee of the Red Cross from Bosnia and Herzegovina. (Woodward, 1995b, p. 281) America's support for Bosnia's territorial integrity and lack of will to engage militarily, together with the European Communities' unarticulated attempts to reach an agreement between the warring parties, blocked the possibility of effectively curbing the war until the summer of 1995.

\footnotetext{
${ }^{9}$ The United States considered war a European problem, with Secretary of State James Baker stating that "we don't have a dog in this fight".

${ }^{10}$ The Bosnian Serb Army, Muslim-dominated Bosnian Army and Bosnian Croat Army were reinforced by military and paramilitary forces from Serbia and Croatia and volunteers mainly from Muslim countries.

${ }^{11}$ This mission was a simple extension of the existing UNPROFOR operation in Croatia.
} 


\section{THE DAYTON AGREEMENT: REALITY BETWEEN PEACE AND EFFICIENCY}

In terms of the American decision to militarily engage in the war, it is important to refer to a timing and changed political and security context, followed by the post-Cold War 'battle of concepts'. Ethnic warfare in Bosnia was the locus of humanitarian interventionist outrage in the first half of the 1990s, and US policy and attitudes towards it delineated the extent of early humanitarian interventionism. (Wertheim, 2010 p. 151) Named as 'The Endgame Strategy', a new diplomatic approach was aimed to end the war and to maintain a single, though divided, state in which the warring parties would be separated. (Mokhiber and Young, Frontline 2015) The 1992 reality was finally accepted, but it became crucially marked by the horrific consequences of the war that deepened ethnic divisions in a way that would prevent reconciliation to this day. Additionally, at the time of opting for the Dayton format conference, due to the bombing of Serbian positions by the NATO pact, as well as the allied Croat-Bosniak offensive actions on the ground, the Serbian side was at a loss for the first time in relation to the size of the territory it controls. Namely, compared to three-quarters of the territory that was under Serbian control, in October 1995 this amount was reduced to $49 \%$, approximately as much as was foreseen in previous peace initiatives. On the other hand, Croats controlled $21 \%$ of the territory (slightly more than international calculations), while Bosniaks controlled the remaining $31 \%$ of the territory of the former socialist republic. The situation on the ground seemed to suit the negotiating objectives, which proved that the outcome of the agreement was meant to formalize the situation on the ground when it became acceptable. Of course, neither side has fulfilled its maximalist demands, primarily in terms of the possible unification of the Serb and Croat dominated parts of the territory with neighboring countries. In these circumstances, it took three weeks of American led negotiations to achieve the General Framework Agreement for Peace in Bosnia and Herzegovina that was finally reached on 21 November 1995 and formally signed in Paris on December 14. Although it will become a commonplace to state that the Dayton Agreement was an agreement "designed to end the war, not to build the state", the result was a comprehensive peace plan that looked beyond the immediate cessation of hostilities to the prospects for long-term stability and the reconstruction of a multi-ethnic state of Bosnia and Herzegovina. Consisting of eleven annexes, devoted to dealing with different aspects of building peace in Bosnia, it represented both military resolution and a sustainable framework for peacebuilding and state-building. Regarding the first aim of negotiations - ending of hostilities, the parties agreed to establish a durable cessation of hostilities, to withdraw their military forces from four-kilometer-wide "zone of separation" dividing the two entities, to negotiate numerical limits on military forces, to ensure free movement of civilians 
throughout of Bosnia, including the return of refugees to their homes, and to cooperate in the investigation and prosecution of war crimes. (Paris, R. 2004, p.99) In terms of international military presence, the agreement called for the establishment of a multinational military Implementation Force (IFOR) under NATO command to monitor the implementation of the military aspects of Annex 1, as well as "to assist in the implementation of nonmilitary aspects, such as providing security for elections and helping ensure the relocation of refugees and displaced persons". (Dayton Peace Agreement, Annex 1a 1995)

Regarding the political and legal framework, the country was divided into two ethnic subunits - the entities, the "Federation of Bosnia and Herzegovina", consisted of areas mainly controlled by Muslims and Croats and the "Republic of Srpska" controlled by Serbs, with a clear division in power and responsibilities between national and entity-level governments. (Dayton Peace Agreement, Annex IV, 1995) Annex IV, which includes the Constitution of Bosnia and Herzegovina, has split the country into two parts, based on the war-time separation lines, thus creating two ethnically distinct regions in the country. This arrangement was the subject of vast criticism, which suggested that it confirms ethnic division and creates a system that would prevent reconciliation in the future. However, having Croats and Muslims, who are together in a formal federation but have different goals, and Serbs in the Republic of Srpska having other aims, with little space for overlapping, the only way to get these people to stay in one country was to have a very decentralized state. Therefore, the power-sharing became essential in order to reach an agreement that every party could sign. Bosnian Serbs won recognition of the Republic of Srpska as a Bosnian Serb entity within the larger state of Bosnia and Herzegovina. As an entity, the Republic of Srpska is not an independent country, meaning that Serbs did not achieve their maximalist goals that could be seen as a full secession. But it is given the power most often associated with sovereignty - the right to maintain its own army and police force governing the Bosnian municipalities bordering Serbia within a contiguous territory, and a Serbian political structure. (Dayton Peace Agreement, Annex IV, 1995) Along with self-governance as an entity, the Dayton Accord permits the Republic of Srpska to have a 'special parallel relationship' with Yugoslavia, meaning Serbia.

When it comes to the political organization, the Constitution specifies that "Bosnia and Herzegovina shall be a democratic state" ruled by the collective body - The Presidency of Bosnia and Herzegovina, consisting of three Members: one Bosniak and one Croatian, each directly elected from the territory of the Federation, and one Serbian, directly elected from the territory of the Republic of Srpska. (Dayton Peace Agreement, Annex IV 1995) Additionally, the equal representation of the divided country is provided by establishing a bicameral parliament, consisting of two chambers - the House of Peoples and the House 
of Representatives. This framework reflected the needs of each side to be fully represented, autonomous, and free in developing their own national identity based on the internal right of self-determination. It is obvious that the agreement explicitly sought to transform Bosnia into a liberal democracy based on the belief that the building of a (liberal-democratic) state is a precondition for sustainable peace and the rule of law. The theoretical basis was found in the idea of liberal peace, which assumes that the building a liberal-democratic state creates preconditions for a peaceful and stable environment. Article 2.1 of the Constitution of Bosnia and Herzegovina claims that "Bosnia and Herzegovina shall be a democratic state, which shall operate under the rule of law and with free and democratic elections". (Dayton Peace Agreement, Article 1, Annex IV 1995) However, one cannot deny that the three-way division "reflects the entrenched ethnic positions adopted during the war and persisting in the postwar environment." (Richmond, Franks, 2009 p. 55). It is an undeniable argument that although the Dayton Accords put in place a decentralized structure of government in order to bring all three sides of the conflict to the negotiating table, it ultimately institutionalized the ethno-religious differences created by the civil war. (Richmond, Franks, 2009, p. 54). This was quickly proved at the first test for the newly created states - the first post-war election in Bosnia in 1996. Namely, the results soon confirmed that the system established resulted in the reelection of politicians chosen mostly due to their ethnic belonging rather than political aspirations, which Horowitz described as 'ethnic outbidding'. Additionally, this has created the issue of governance. Namely, instead of holding their own leaders accountable for public policies, the population has been divided over the years between those who see a new enemy or scapegoat for their difficult times in the imperious representatives of the international community and those who are increasingly impatient that the international community will not fully acknowledge its de facto international "protectorate" and thus take over and govern directly. Between these two camps lies a large silent mass increasingly apathetic because they see the outsiders as the "boss." (Hopmann, USIP 1999 p. 8) However, the problem with this type of criticism lies in the fact that it denies the issue referring to a general problem of the state-building practices in which the imposed model "misunderstands the reality of actual countries, which operate differently and often more effectively than the standard by which they are being judged, and is in conflict with the goals of peace and development that statebuilding aims to achieve." (Woodward, 2009a, p. 318)

Unlike formal protectorates established under the United Nations Security Council resolutions, such as the one in Kosovo, Bosnia was established as a sovereign state, although with a quite "flexible Dayton framework that authorized internationals to crucially shape post-conflict agenda in Bosnia while being unaccountable towards local population." (Chandler, 2007, p. 337) This attitude 
opposes quite a common argument that the Dayton Agreement has tied the hands of the international community and created a complex set of political institutions that stymie the building of a strong centralized state and continue to enable ethnically-based political parties to dominate the policy-making process. Thus, criticism of the poor transition towards local ownership and a lack of success in building strong institutions of a central state, institutionalizing ethnic divisions, should take into consideration a responsibility of the external mechanisms of regulation as well. After decades of the state-building operations, it seems that the responsibility lies within international, at least as much within local actors, so the criticism should be referred to both sides. This is a general constraint of the state-building programs since the majority of those belonging to the labeled states interpret the label as a threat of imminent intervention, rather than a program for institutional building and assistance. (Woodward, 2017c, p.181) "Pushing countries too soon into competitive electoral politics not only risks stoking war, sectarianism and terrorism, but it also makes the future consolidation of democracy more difficult" (Mansfield, Snyder 2005 p.39) meaning that imposing the liberal peacebuilding theory can often cause more harm than good. Generally, the poor results of the state-building interventions appear to be a part of this highly criticized concept itself. Indeed, despite many efforts to learn lessons and improve outcomes, most practitioners and researchers concede that there are no successes from which to learn. Many interventions had to be repeated when violence resumed, as in Angola, Liberia, Haiti, Somalia, Sierra Leone, and East Timor. (Woodward, 2009a, p. 316) The 2016 OECD report presented results showing that in the last quarter of a century, the number of countries that managed to graduate out from the category of failed or fragile ranges from zero to four. (OECD DAC 2014, p. 16.)

This is why critics of the Dayton Agreement seem accepted only to some extent since the agreement itself provided a sustainable peace, although one has to be aware that success itself can be differently understood. While some define success as simply as "the establishment of stability and a rule of law," others view it as a more complex and multi-layered concept. (Seth, 2005 p. 2) Unlike many agreements in the Balkans that have sown the seeds of potential future conflicts, the Dayton Agreement achieved its basic peacebuilding goals, with indisputable shortcomings in the field of management and building efficient institutions. However, criticism in this regard lacks in highlighting external responsibility. As it has been proven many times before, any peace process in the Balkans needs to be understood as a complex political dynamic between local and international actors in time and space.

In this regard, it is useful to refer to the perspective that highlights the importance of the peace dimension of the agreement. Trapara places the Dayton Accords in the category of generous peace, using a realistic classification of vengeful 
and generouspeace. Namely, comparing it to the Versailles Agreement as an example of the first type of agreement, he finds in the Dayton Agreement precisely the characteristics of a generous peace (Trapara, 2016, p. 54) which, with some deviations ${ }^{12}$, enabled all parties to significantly achieve their political and national ambitions in Bosnia. Donald Horowitz points out that it is often true that the majority population is more discontented with ethnic power-sharing schemes than are minorities, at least in Northern Ireland, Belgium, and Bosnia. (Horowitch, 2014, p. 18) In the case of Bosnia, this can be related to the identity issue of warring parties. Namely, major criticism and request for revision of the agreement are coming from Muslims in Bosnia, asking for "unitary identity". However, the Dayton Agreement "wrote down" the identity of Bosnia in a way that best suits its history, with an organization able to preserve its independence and territorial integrity. Providing the entities with the characteristics of statehood is a repetition of the previous orientation of constituent peoples, giving the entities the right to special parallel ties with neighboring states. (Trapara, 2016, p. 56) One cannot deny that with its complex history and mixture of identities throughout historical processes, any attempt in further unification of the state would be non-viable. On the contrary, as Trapara rightly points out "without particular identities, there is no identity of Bosnia and Herzegovina". This represented the essence of the Dayton Agreement, and at the same time, the most sustainable solution to the Bosnian identity issue in relation to all others ever tried. However, we are witnessing a large scale of criticism of the effectiveness of the system in Bosnia, which is based on the demand for the unitarization of the state in order to allegedly improve the effectiveness, which is contrary to the spirit of the Dayton Agreement. To some extent, it can be expected that such demands come from Bosniaks who, through calls for unitarization, seek to preserve a unitary Bosnia and thus ensure the survival of the state for which they fought. Since they did not achieve their maximalist demands through the Dayton format, requests for unitarization under the guise of demands for improving the efficiency of the system represent a continuous struggle for an independent and unitary Bosnia. This finally provokes intolerance among Serbs and continues to penetrate the Republic of Srpska's aversion to remain within a federalized Bosnia and Herzegovina. This circle of maximalist demands returns the problem to the pre-Dayton period and creates security challenges that overcome the problems of the non-functionality of Dayton's Bosnia and create the seeds of potential conflicts. The years before the Dayton Agreement showed that insisting on the maximalist goals of either side in Bosnia was not a fertile ground for lasting peace, which is the most significant value in the region drastically affected by wars and destruction. Lastly, similar sayings on

\footnotetext{
${ }^{12}$ Such as the absence of the third - Croatian entity, or leaving the status of Brcko unresolved.
} 
the non-viability of Dayton's Bosnia come from the major sponsors of the agreement. This is a paradox since the outsiders firstly created the state by institutionalizing ethnically defined political rights for previously explained reasons. Additionally, while requiring extensive decentralization as a model in other state-building ventures (such as Kosovo and Macedonia), foreigners seem to be "working hard to reverse the powers granted by the Dayton Peace Accord, in 1995, to local and entity governments in Bosnia and Herzegovina and to build a strong and capacious central government instead". By contrast, it was argued that centralization in Bosnia and Herzegovina was necessary because the duplication of functions of so many layers of government was unsustainable. (Woodward, 2009a, p. 326) Nevertheless, we are of the opinion that between peace and the efficiency of public administration, there is a categorical space for improvement, which does not necessarily have to be in the form of unitarization because it essentially jeopardizes the identity of divided ethnic communities. Somewhat paradoxically, the division in the case of Bosnia meant securing the right to self-determination within one state. Alternative solutions would potentially upset the balance that ensured the major achievement of the Dayton negotiations - peace in a multinational Bosnia.

\section{CONCLUSION}

The disunity of international actors towards the war in Bosnia and the refusal to accept the reality, based on the ethnic division and the aspirations of each side to achieve its goals in the war, filled the Bosnian 'powder keg' for three years before the Dayton Agreement was finally reached. When it became clear that the lesson that had to be learned in Croatia was repeated and that unilateral punishment of one side could not stop the bloodshed, the reality gave rise to an agreement that was able to force all warring parties to negotiate. Of course, this was preceded by military intervention and the redrawing of territorial gains in the bloody years of the war. Large-scale criticism of the ineffectiveness of divided Bosnia in recent years seems to come from those who have not understood that a highly decentralized Bosnia is the only possible solution in the situation where each ethnic group is asserting its right to self-determination. This right in the context of Bosnia protects particular identities, but at the same time maintains its statehood. Finally, Dayton's Bosnia represents a compromise between the demand for self-determination and the prevention of further disintegration that led to the devastation of war. It is undisputed that the space between peace and effective governance is a space for the improvement of the system, but it does not necessarily mean unitarization since this can endanger the foundation of 25 years lasting peace. Sayings that the accords provided peace for two and a half decades, but at "the price of a state carved up along ethnic lines and hostage to 
nationalism" (Sito-Sucic, Guardian, 2015), have to be understood in the context of a comprehensive reach of the agreement. Since the dilemma regarding the nature of the war was never actually resolved, despite the formal admission of Bosnia to the United Nations and qualification of the war as Serbian aggression, in practice, the international community had to seek a compromise between the three warring parties. Therefore, the Dayton Agreement was an expression of the reality that was largely ignored in the years of war that preceded the agreement. The agreement finally represented a compromise between the aspirations of different warring parties, which was the core principle of the second approach, acknowledging three warring parties' goals that remain relevant even today in a peaceful environment. When criticizing the concept of Dayton's peace, one has to keep in mind that the goal of the agreement was to end wars between parties who were engaged in a bitter contest over the kind of state and borders they sought. Finally, but somewhat paradoxically, the Dayton Agreement became an agreement that confirmed the territorial gains, though only after those gains were corrected by NATO military intervention and became acceptable to the patrons of the agreement. It is undeniable that the brutality of the war influenced America's determination to engage, but the question remains whether the brutality and greatest suffering of civilian casualties in the post-Second World War Europe was a justified cost for the late engagement and favorable territorial percentage as a condition for the final peace agreement.

\section{REFERENCES}

Chandler, David. (2007). From Dayton to Europe, in Peacekeeping, 12:3, pp. 336349.

Hopmann, P. Terrence. (1999). Building Peace and Security in Post-Cold War Eurasia: The OSCE and U.S. Foreign Policy. Peaceworks, no.31. United States Institute for Peace.

Horowitz, Donald. (2014). Ethnic Power Sharing: Three Big Problems. Journal of Democracy. 25. pp. 5-20.

Mokhiber Jim and Young Rick. (2015) Nation Building in Bosnia: how efforts to stop the war turned into a broader responsibility for building a lasting peace, Frontline, November 14 2015, Retrieved from: https://www.pbs.org/ $\mathrm{wgbh} / \mathrm{pages} /$ frontline/shows/military/etc/peace.html, accessed on May 2, 2020.

OECD DAC (2014). Fragile States 2014: Domestic Revenue Mobilisation in Fragile States. Paris OECD.

Paris, Roland. (2004). At War's End: Building Peace after Civil Conflict. Cambridge: Cambridge University Press. 
Richmond, Oliver. and Franks, Jason. (2009) Liberal Peace Transitions: Between Statebuilding and Peacebuilding. Edinburgh University Press.

Seth, Jones. (2005) Establishing Law and Order After Conflict. Santa Monica, CA: RAND. pp. 11-24.

Sito Sucic, Daria. (2015). Bosnia marks 20 years of peace deal with a time capsule of hope, Guardian, Sun 22 Nov 2015, Retrieved from https://www.the guardian.com/world/2015/nov/22/bosnia-marks-20-years-of-peace-dealwith-a-time-capsule-of-hope, accessed on May 17, 2020.

Toal, Gerard and Dahlman, Carl. (2011). Bosnia Remade: Ethnic Cleansing and Its Reversal. New York: Oxford University Press.

Trapara, Vladimir. (2016) Višedimenzionalni istorijski značaj Dejtonskog sporazuma. In: Dejtonski mirovni sporazum - dve decenije mira i pouke za svet. Fakultet političkih nauka, Banja Luka; Institut za međunarodnu politiku i privredu, Beograd, Beograd, pp. 53-62.

Wertheim, Stephen. (2010) A solution from hell: the United States and the rise of humanitarian interventionism, 1991-2003, in Journal of Genocide Research, 12(3-4),

September-December 2010, pp. 149-172.

Woodward, Susan. (2009a), Varieties of State-Building in the Balkans: A Case for Shifting Focus, Berghof Handbook Dialogue 8, pp. 316-333.

Woodward, Susan. (1995b) Balkan tragedy: chaos and dissolution after the Cold War. Washington, D.C.: Brookings Institution.

Woodward, Susan. (2017c), The Ideology of Failed States: Why Intervention Fails? Cambridge University Press.

Mansfield Edward and Snyder Jack. (2005). "Prone to Violence: The Paradox of the Democratic Peace. The National Interest No. 82 (Winter 2005/06). pp. 39-45. 


\section{NASLEĐE DEJTONA - 25 GODINA IZGRADNJE MIRA U BOSNI I HERCEGOVINI}

Apstrakt: Dvadeset peta godišnjica od potpisivanja Dejtonskog mirovnog sporazuma, kojim je okončan rat u Bosni i Hercegovini, predstavlja povod da se razmotre njegovi dometi i oceni dvoipodecenijsko nasleđe. Od trenutka kada je stupio na snagu do danas, ovaj sporazum je bio predmet različitih kritika, koje su često zanemarivale složene okolnosti u kojima je postignut, kao i važnost njegovog ključnog postignuća - mira. Zbog toga, ovaj rad razmatra okolnosti koje su odložile postizanje konačnog mirovnog sporazuma u Bosni i Hercegovini i produžile građanski rat za tri godine, kao i političke okolnosti koje su dovele do pregovora koji su završeni konačnim postizanjem mirovnog sporazuma. Opšti okvirni sporazum za mir u BiH, kojim je okončan građanski rat, može se analizirati samo delimično, imajući u vidu značaj vremenske distance koja je potrebna za razumevanje njegovog šireg značaja. Stoga, rad nastoji da rezultate sporazuma predstavi u odnosu na dva osnovna cilja: izgradnju mira i izgradnju države u Bosni, imajući u vidu da su oni međusobno uslovljeni, te da svaku procenu njihove ostvarenosti treba shvatiti u širem kontekstu koji uključuje obe dimenzije.

Kjučne rečr: Bosna i Hercegovina, građanski rat, Dejtonski sporazum, izgradnja mira, izgradnja države.

Received: $15 / 8 / 2020$

Accepted: 24/8/2020 